\title{
9. Brief Notes on the Eodiscids* I, Their Classification with a Description of a New Species and a New Variety.
}

\author{
By Teiichi KobaYaSHI**. \\ (Comm. by H. YABE, M.I.A., Jan. 12, 1943.)
}

Matthew was the first to classify eodiscids. While he had classified them into four sections in 1896, Raymond established the Eodiscidae in 1913 to include Eodiscus, Goniodiscus and Weymouthia. Later Pagetia Walcott, Delgadoia Vogdes (=Delgadodiscus Kobayashi) and Hebediscus Whitehouse were added to them and I myself established the Pagetidae to comprise Pagetza and Dipharus. For Raymond's Goniodiscus Howell proposed Calodiscus in 1932, because it was a homonym of Müller and Troschel's Goniodiscus, 1842, and subsequently in 1937 Resser pointed out that Dawsonia Hartt, 1868, which had long been overlooked, must be used in place of Calodiscus, but in my opinion these two are both valid names because Calodiscus and Dawsonia are different in the number of thoracic segments that they have as well as in other respects.

Recently $\mathrm{I}^{\mathrm{i}}$ re-examined the whole group of eodiscids, and found that Cobboldites, Paradiscus, Metadiscus, Spinodiscus, Brevidiscus, Deltadiscus, Alemtejoia, Eopagetia and Mesopagetia should be added to them. Not counting the eight species ${ }^{2}$ of which little is known, as well as another eight species) which were referred to the eodiscidian genera incorrectly, there are forty-five species and three varieties which are classified here into fifteen genera and three subgenera in five

* Miscellaneous Notes on the Cambro-Ordovician Geology and Palaeontology, Nos. 11-12.

** This paper is the result of studies which I am undertaking with a research grant from the Department of Education. I wish here to express my thanks to the officials of the department for financial support and to Prof. H. Yabe for his continuous encouragement and for presenting the two companion papers to the academy.

1) T. Kobayashi, On the Eodiscids (in preparation).

2) Microdiscus sp. undt. aff. M. meeki by Walcott, 1890, (undescribed). Microdiscus sp. undt. Toll, 1899.

Microdiscus orientalis Walcott, 1905.

Microdiscus cfr. sculptus Hicks by Miquel, 1905, (undescribed).

Microdiscus sp. nov. by Miquel, 1912, (undescribed).

Microdiscus emerci Czarnocki, 1927, (undescribed).

Microdiscus sp. by Reed, 1934, (undescribed).

Calodiscus aff. oelandicus Westergård, 1936, (undescribed).

3) Dolichometopus tatei Woodward, 1884

Microdiscus subsagittatus Tate, 1892

"Lorenzella".

Microdiscus kochi Toll, 1899 "Lorenzella tatei

Microdiscus lenaicus Toll, 1899 Ciceragnostus.

Ptychoparia czekanowski Toll, 1899

Ciceragnostus.

Ptychoparia meglitzki Toll, 1899 Levisia?

Strenuella (?) attleborensis vigilans Matthew, 1899 Strenuella?

Ptychoparia (?) annro Cobbold, 1910 Strenuella? Strenuella. 
families including six subfamilies as below. (Type species of each genus is marked by an asterisk).

Agnostida Kobayashi, 1935.

Microtrilobites, miomeric and isopygous.

Dawsoniidea Kobayashi (nov.) (=Eodiscidea Richter, 1932, pars.)

Agnostida having two or three segments in thorax and regularly furrowed axial lobe of pygidium; eyes and proparian facial sutures occasionally present; basal sidelobes of glabella always absent1).

\section{Eodiscidae Raymond, 1913.}

Hypoparian Dawsoniidea with distinct axial lobe and trisegmented thorax.

1 a. Calodiscinae Kobayashi, nov.

Eodiscidae having smooth cephalic border.

1. Calodiscus Howell, 1935, em. (=Goniodiscus Raymond, 1913).

Eodiscidae with long unfurrowed glabella and furrowed pygidium; nuchal spine absent; borders smooth.

Agnosuts lobatus Hall*, 1847

Microdiscus parkeri Walcott, 1886.

2. Cobboldites Kobayashi, nov.

Similar to Calodiscus, but pleural and ring furrows obscured on the pygidium.

Microdiscus comleyensis Cobbold*, 1910

Eodiscus simplex Cobbold, 1931,

Cobboldites gracilis Kobayashi, nov. (=Microdiscus cfr. helena by Burr in Grabau, 1900, pl. 33, fig. 3).

11 b. Eodiscinae Kobayashi, nov.

Eodiscidae having short glabella, tuberculated cephalic border and unfurrowed pleural lobes of pygidium.

3. Paradiscus Kobayashi, nov.

Eodiscidae with no spine on the posterior side of cephalon; transglabellar furrows occasionally present.

Microdiscus speciosus* Ford*, 1873

Microdiscus helena $\cdot$ Walcott, 1889

Microdiscus robustus Kobayashi, nov. (=Microdiscus speciosus by Lake, 1907, pl. 3, fig. 7).

4. Eodiscus Matthew, 1896.

Similar to Paradiscus but having spines on the posterior side of the cephalon: transglabellar furrows very weak or absent.

Microdiscus pulchellus Hartt, 1381

Micradiscus belli-marginatus Shaler and Foerste, 1888

Microdiscus schucherti Matthew*, 1896

Microdiscus bellimarginatus insularis Matthew, 1899.

11 c. Spinodiscinae Kobayashi, nov.

Eodiscidae having a nuchal spine and crenulated cephalic border.

1) For further distinctions of this superfamily from the Agnostidea, see the next paper. 
5. Metadiscus Kobayashi, nov.

Spinodiscinae with furrowed pleural lobes of pygidium.

Microdiscus sculptus Hicks*, 1871

Microdiscus haimantensis Reed, 1910

Eodiscus fusifrons Saito, 1934

Calodiscus foveolatus Howell, 1935

Calodiscus oelandicus Westetgård, 1936

Metadiscus bunkeiensis Kobayashi, nov.

Metadiscus bunkeiensis sulcatus Kobayashi, nov.

6. Spinodiscus Kobayashi, nov.

Similar to Metadiscus but having unfurrowed pleural lobes of pygidium.

Microdiscus punctatus Salter*, 1864 (= Microdiscus eucentrus Linnarsson, 1883) Microdiscus scanicus Linnarsson, 1883 (a variety of punctatus)

Microdiscus convexus Walcott, 1887

Spinodiscus matthewi Kobayashi, nov. (=Microdiscus pulchellus by Matthew, 1896, pl. 17, figs. 8 a).

$1 \mathrm{~d}$. Brevidiscinae Kobayashi, nov.

Intermediate between the Dawsonidea and Agnostidea, but tentatively placed here.

7. Brevidiscus Kobayashi, nov.

Similar to Calodiscus but having a shorter glabella: lunate preglabellar depression and transglabellar furrows occasionally present.

Brevidiscus lunulatus Kobayashi*, nov. (=Microdiscus lobatus by Walcott, 1886, pl. 15, fig. 1 a)

Brevidiscus (?) agnostoides Kobayashi, nov. (=Microdiscus lobatus by Walcott, 1886, pl. 16, fig. 1)

Brevidiscus (?) troyensis Kobayashi, nov. (=Microdiscus lobatus by Walcott, 1886, pl. 16, fig. 1 a).

II. Dawsoniidae Resser, 1937, em.

Hypoparian Dawsoniidea with crenulated cephalic border and bisegmented thorax.

8. Dawsonia Hartt, 1868 (non Nicholson, 1873 and Fritsch, 1879).

Dawsoniidae having longiconic glabella and furrowed pygidium.

Dawsonia dawsoni Hartt*, 1868 (=Microdiscus dawsoni Billings)

Dawsonia spinifera Kobayashi, nov. (=Microdiscus dawsoni by Matthew, 1896, pl. 17, fig. 5 a-c)

Dawsonia canadensis Kobayashi, nov. (=Pygidium of Microdiscus praecursor Matthew, 1896, text-fig.).

9. Deltadiscus Kobayashi, nov.

Dawsoniidae with breviconic glabella and median preglabella furrow.

Deltacandus praecursor (Matthew*) (Eodiscus punctatus praecursor Matthew, 1885, cephalon only).

III. Dipharidae Kobayashi, nov.

Proparian Dawsonidea with eyes and depressed lunate cephalic border and trisegmented thorax.

10. Hebediscus Whitehouse, 1936.

Dipharidae with, eyes and eye-ridges.

Ptychoparia attleborensis Shaler and Foerste*, 1888

Hebediscris cobboldi Resser, 1937. 
11. Dipharus Clark, 1923.

Dipharidae with transglabeller furrow and stalked eyes.

Dipharus insperatus Clark*, 1923

Dipharus peculiaris Kobayashi, nov. $(=$ Pagetia attleborensis by Cobbold, 1931, pl. 38, fig. 6).

IV. Pagetiidae Kabayashi, 1935.

Proparian Dawsoniidea with bisegmented thorax.

12. Pagetia Walcott, 1916, is the only known genus of the family which is divided into the following three subgenera.

12 a. Eopagetia Kobayashi, nov.

Pagetia with thoracic segments of the same outline and ribbed pleural lobes of pygidium: median preglabellar furrow absent.

Microdiscus significans Etheridge*, 1902

Eodiscus spiniger Saito, 1934

Eopagetia resseri Kobayashi, nov. (=Pagetia clytia by Resser, 1937, pl. 2, fig. 8).

12 b. Mesopagetia Kobayashi, nov.

Pagetia with thoracic segments of the same outline: pleural furrows of pygidium weak : median preglabellar furrow occasionally pres@nt.

Pagetia clytic Walcott*, 1916

Microdiscus griesbachi Reed, 1910

Pagetia fossula Resser, 1938

Pagetia maladensis Resser, 1939.

12 c. Pagetia Walcott, s. str.

Pagetia with median preglabellar furrow and smooth pleural lobes of pygidium: posterior thoracic segment broader than the anterior one and its pleural end pointed antero-laterally.

Pagetia bootes Walcott, 1916.

V. Weymouthiidae Kobayashi, nov.

Smooth Dawsoniidea with trisegmented thorax; eyes and facial sutures occasionally present.

$\mathrm{V}$ a. Weymouthiinae Kobayashi, nov. Hypoparian Weymouthiidae with tuberculated cephalic border.

13. Weymouthia Raymond, 1913.

Agnostus (?) nobilis Ford*, 1872

$\mathrm{V}$ b. Delgadoiinae Kobayashi, nov.

Weymouthiidae with eyes and non-tuberculated cephalic border.

14. Delgadoia Vodges, 1917 (=Delgadodiscus Kobayashi, 1935).

Delgadoiinae with a caudal spine ; eyes and proparian facial sutures occasionally present.

Microdiscus caudutus Delgado*, 1904

Microdiscus subcuudatus Delgado, 1904

Microdiscus venseslaci Delgado, 1904.

15. Alemtejoia Kobayashi, nov.

Delgadoiinae with no rows of tubercles on the cephalic border, nor caudal spine; eyes occasionally present. 
Microdiscus souzai Delgado, 1904

Microdiscus woodwardi Delgado, 1904

Description of Metadiscus bunkeiensis sp. nov. and its variety, sulcata, var. nov.

Pagetia (Eopagetia) sp. nov, Kobayashi and Aoti, Proc. 18 (1942), 305, (listed).

Several detached shields of Metadiscus bunkeiensis nov. are contained in the Bunkel collection. Because of the poor state of preservation I thought at first that they had eyes and facial sutures but later found on a better preserved specimen that the parts thought to be the sutures and eyes must be broken margins. Two cephala at hand are almost identical with that of $M$. haimantensis" ${ }^{1}$ except for the smooth test of the carapace and presence of faint crenulation on the border seen in one of the two cephala (fig. 1). On these accounts this species agrees with $M$. fusifrons ${ }^{2}$ but its occipital spine is very short.

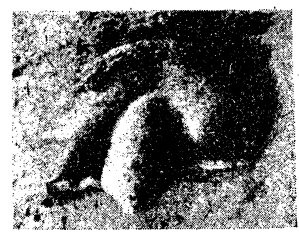

1

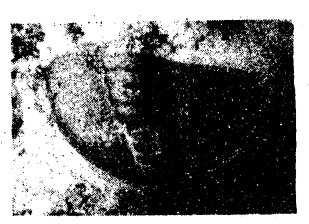

3

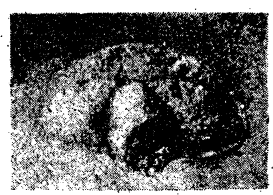

2

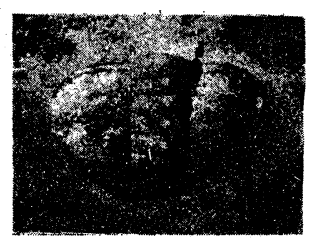

4

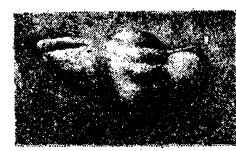

5

Fig. 1, 3 \& 5. Metadiscus bunkeiensis Kobayashi, (nov.)

Fig. 2 \& 4. Metadiscus bunkeiensis var. sulcata Kobayashi, (nov.)

The third cephalon (fig. 2), though similar to the preceding, differs in having a pair of lateral furrows and an occipical one, all distinct. Therefore the name, sulacta, is proposed here for this cephalon. Though the posterior end of its glabella is broken, its occipital ring is probably not so much projected behind as that of the typical form.

The pygidia from Bunkei can also be classified into two kinds. One (fig. 4), like that of haimantensis, has a tubercle on each ring of

1) F. R. Cowper Reed (1910), The Cambrian Fossils of Spiti. Palaeontol. Indica. ser. 1i, vol. 7, Mem. no. 1, p. 7, pl. 1, figs. 12-13.

2) K. Saito (1934), Older Cambrian Trilobita and Conchostraca from North-Western Korea. Japan. Jour. Geol. Geogr. vol. 9, 218, pl. 25, figs. 12-16. 
the axial lobe which is lacking in four others. The tuberculated one, however has one or two more rings on the axis than does haimantensis and its test is smooth; the non-tuberculate ones (figs. $3 \&$ 5) resembles that of fusifrons but the axis is a little broader. Pleural furrows can only be seen in the pygidia at hand only when light is thrown sideways on the specimen.

Because these specimens are fragmentary, it is impossible to determine which pygidium goes with which cephalon, but for the time being the non-tuberculated pygidium is referred to the typical form, the tuberculated one to the varietal form.

Occurrence:-Ptychoparia zone in the Majo formation in the South of Kanairi, Bunkei area, South Chosen. 